\title{
Time-study of moose (Alces alces L., 1758) geophagia activity in the Central Yakutia
}

\author{
Valentina V. Stepanova*, Alexandr V. Argunov, Ruslan A. Kirillin \\ \& Innokentiy M. Okhlopkov
}

\begin{abstract}
Geophagia of wild hoofed mammals was recorded using camera-traps in five mineral licks of the Central Yakutia (Russia). In total, 235 camera-trap-days are spent, breakdown by months: June - 34, July - 60, August - 65, September - 60, October - 16. Over this period, we registered 122 visits of moose. Presence of 215 moose on the mineral licks is documented, among them -24 visits of females with calves. The average geophagia of moose $(\mathrm{M} \pm \mathrm{SD})$ is $8.7 \pm 7.8 \mathrm{~min}(\lim 1-40 ; n=125)$. The average number of visits per day is 3.1 ( $\lim 1-8 ; n=54)$. The maximum number of moose staying on a mineral lick at the same time amounted to 4 animals. The maximum number of moose visited a licks per day amounted to 6 animals (apart from repeated visits). Monthly visiting of licks is as follows: June - 43.3\%, July - 49.2\%, August - 5.8\%, September - 1.7\%, and October - 0\%. The sex ratio of using the salt mineral licks was as follows: bulls $47.6 \%(n=10)$, cows $-52.4 \%(n=11)$.

How to cite this article: Stepanova V.V., Argunov A.V., Kirillin R.A., Okhlopkov I.M. 2017. Time-study of moose (Alces alces L., 1758) geophagia activity in the Central Yakutia // Russian J. Theriol. Vol.16. No.2. P.185-190. doi: 10.15298/rusjtheriol.16.2.07
\end{abstract}

KEY WORDS: mineral licks, geophagia, moose, visiting, duration.

ValentinaV. Stepanova [valstep@yandex.ru], Institute of Cryolithic Zone Biological Issues of the Siberian Branch of the Russian Academy of Sciences, Laboratory studies of ecosystem Cold Regions, Lenin Avenue 41, Yakutsk 677891, Republic of Sakha (Yakutia), Russia; AlexandrV. Argunov [argal2@yandex.ru], Institute of Cryolithic Zone Biological Issues of the Siberian Branch of the Russian Academy of Sciences, Laboratory studies of ecosystem Cold Regions, Lenin Avenue 41, Yakutsk 677891, Republic of Sakha (Yakutia), Russia; Ruslan A. Kirillin [ruslan.kirillin@gmail.com], Institute of Cryolithic Zone Biological Issues of the Siberian Branch of the Russian Academy of Sciences, Laboratory studies of ecosystem Cold Regions, Lenin Avenue 41, Yakutsk 677891, Republic of Sakha (Yakutia), Russia; Innokentiy M. Okhlopkov [imokhlopkov@yandex.ru], Institute of Cryolithic Zone Biological Issues of the Siberian Branch of the Russian Academy of Sciences, Laboratory studies of ecosystem Cold Regions, Lenin Avenue 41, Yakutsk 677891, Republic of Sakha (Yakutia), Russia.

\section{Хронометраж литофагиальной активности лося (Alces alces L., 1758) в Центральной Якутии}

\section{В.В. Степанова*, А.В. Аргунов, Р.А. Кириллин, И.М. Охлопков}

РЕЗЮМЕ. Регистрация литофагии диких копытных посредством фотоловушек проведена на 5 зверовых солонцах в Центральной Якутии (Россия). Всего проведено 235 фотоловушко-суток, в том числе по месяцам: июнь - 34, июль - 60, август - 65, сентябрь - 60, октябрь - 16. За этот период зарегистрировано 122 одиночных и групповых посещений солонцов. Зафиксировано пребывание на солонцах 215 лосей, включая повторные заходы одних и тех особей. Среди них 24 посещений составили самки с лосятами. Продолжительность литофагии лосей в среднем $(\mathrm{M} \pm \mathrm{SD})$ составила $8.7 \pm 7.8$ мин. (lim $1-40 ; n=125)$. В среднем количество посещений за сутки животными составило 3.1 ( $\lim 1-8 ; n=54)$. Максимальное количество солонцевавших одновременно лосей достигало 4 особей. Максимальное количество лосей, посетивших солонец за сутки, составило 6 особей (не считая повторных заходов). Посещаемость солонцов составила: июнь - 43.3\%, июль $49.2 \%$, август - 5.8\%, сентябрь - $1.7 \%$, октябрь - $0 \%$. Половое соотношение особей, посетивших солонцы, составило: самцы - $47.6 \%$, самки - 52.4\%.

КЛЮЧЕВЫЕ СЛОВА: зверовые солонцы, литофагия, лоси, посещение, продолжительность.

* Corresponding author 


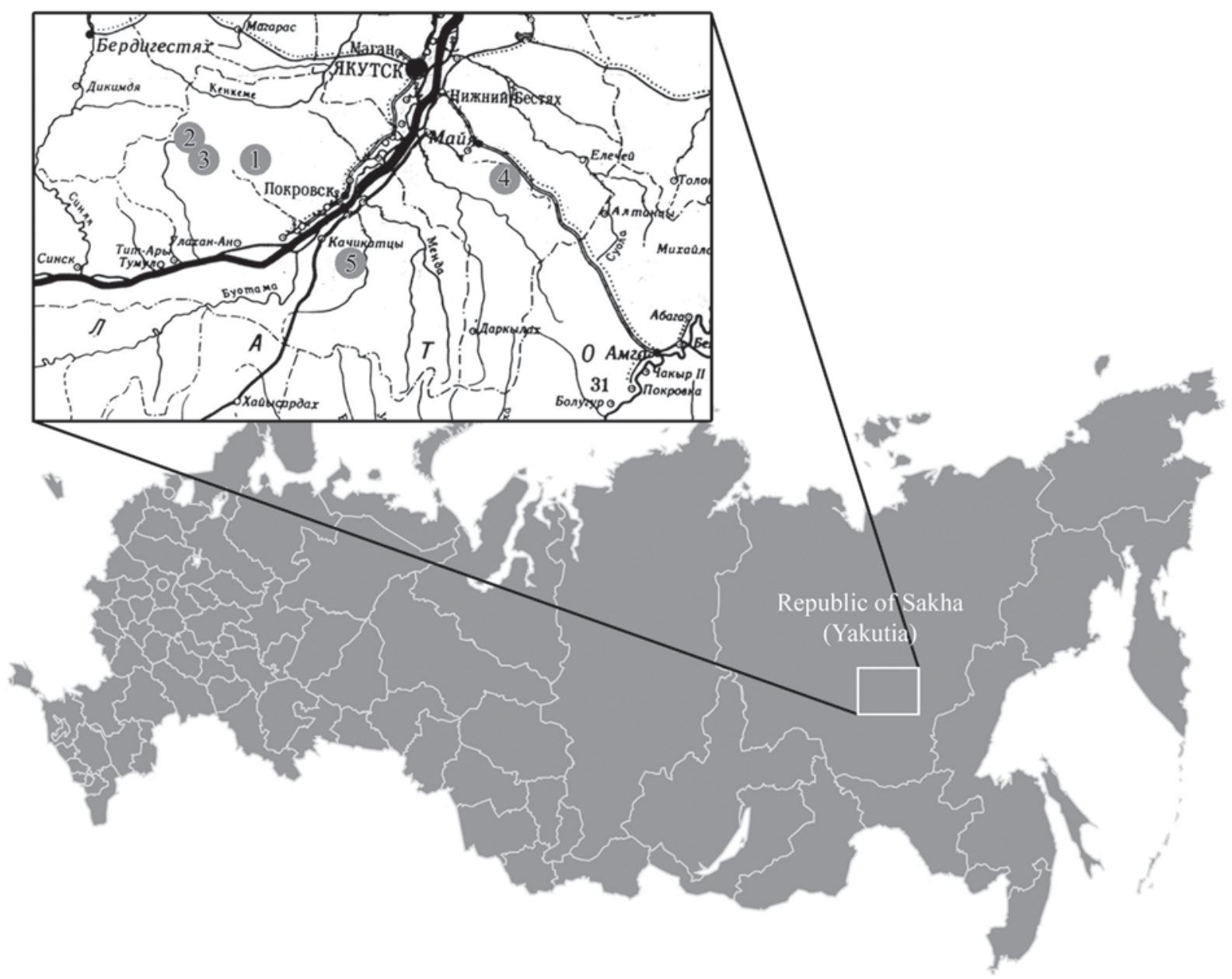

Fig. 1. Map location of mineral licks in Central Yakutia.

\section{Introduction}

The study of geophagia in animals was initiated in the beginning and middle of the 20th century by Soviet geologist P.L. Dravert (1922), American biologist A. Muri (1934) and Soviet biologists A.A. Nasimovich (1938), L.G. Kaplanov (1948) and F.D. Shaposhnikov (1953). Over half a century, there have been no great advances in the study of the subject. Later, the use of salt licks by animals were the focus of the research of Russian scientists V.I. Bgatov (1993a, b, 1997, 2000) and A.M. Panichev (1987a, b, 1990, 1998, 2017), who introduced new terms in this area and suggested new causes of geophagia.

As for foreign literature on the moose geophagia, one can refer to the works by Canadian and American scientists (Hebert \& Cowan, 1971; Carbyn, 1975; Fraser et al., 1980; Fraser \& Hristienko, 1981; Tankersley \& Gasaway, 1983; Couturier \& Barrette, 1988; Filus, 2002; Ayotte et al., 2006; Ayotte et al., 2008; Rea et al., 2013; Lavelle et al., 2014), as well as Finnish researchers (Heikillä \& Härkönen, 1998).
However, this significant part of the ecology of wild ungulates has seen little coverage in the literature. Targeted researches of peculiarities of lick use by wild ungulates in different habitats could fill the gaps in studying this aspect of the large mammals' population ecology.

Many of the above-mentioned biology scientists believe that during the period of the organism's reorganization under the seasonal change of feed ration and physiological changes, wild ungulates experience the need for additional mineral nutrition, which is satisfied by the geophagia of saline soils. In recent years, when explaining the geophagia-driven craving in some animals, the "detoxification-antidiarrheal" hypothesis, or the hypothesis of normalizing the digestive system through the use of clay minerals such as smectite, illite and kaolinite (Panichev \& Golokhvast, 2009) is becoming increasingly popular. According to Panichev \& Golokhvast (2009), the main mechanism of the minerals-living systems interaction is only beginning to open up in the sphere of energy-information interactions.

The area of research can be classified as circumpolar regions, which fall under the regions where geoph- 


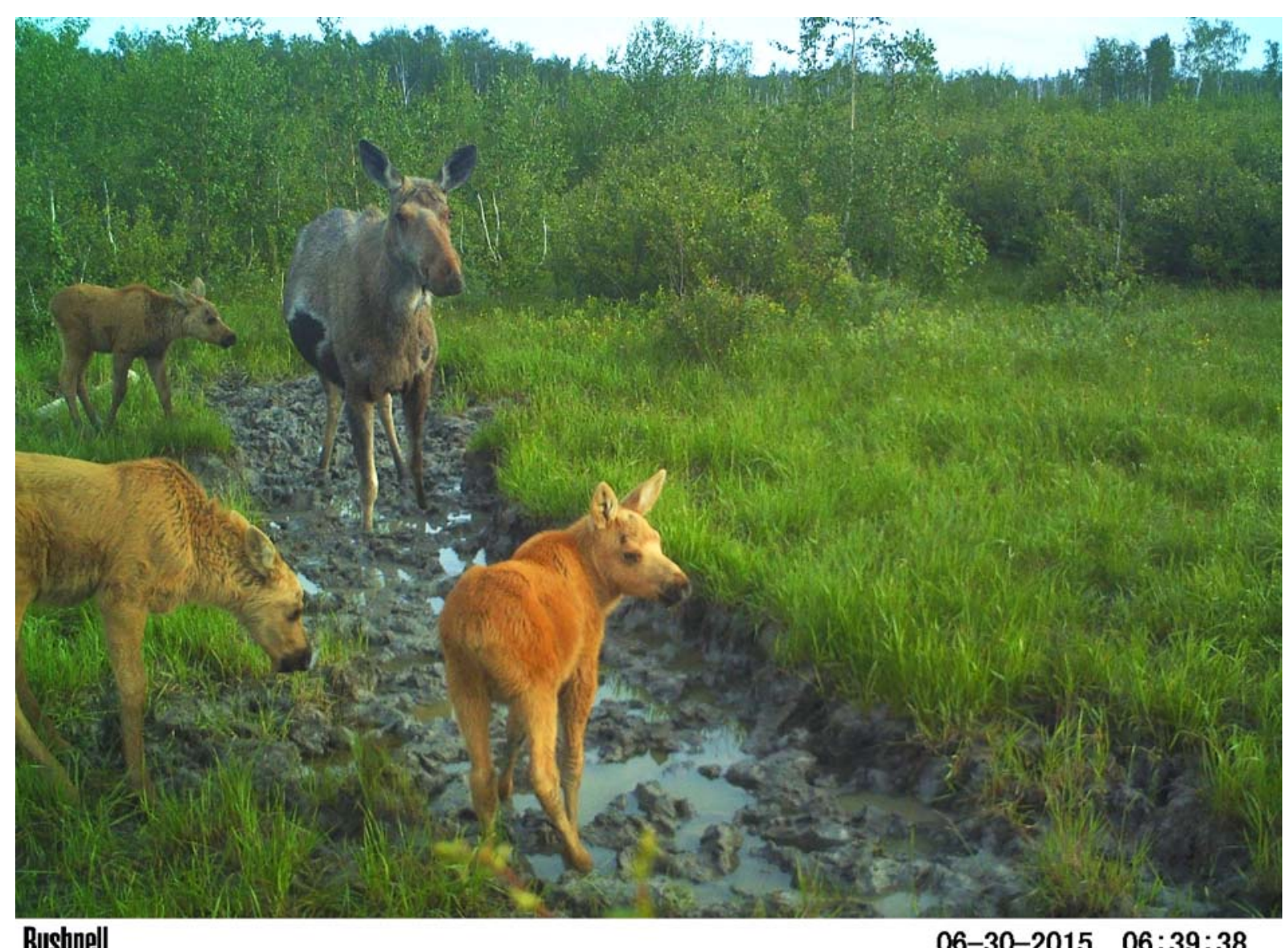

Fig. 2. Moose cow with three calves on the mineral lick.

agia is most manifested (Panichev \& Gulkov, 2001). The study of the geophagia of wild ungulates in Northern climatic conditions is relevant because stressful conditions for the animal's organism such as cold temperatures, sharp change of seasons, accelerated phenology of animals themselves and plants eaten by them, rapid physiological reorganization of the animal's organism from one type of food to another can lead to disorders of the gastrointestinal tract and other organs. We have already covered some aspects of the geophagia peculiarities of wild ungulates in Yakutia in previous works (Stepanova, 2003; Stepanova \& Okhlopkov, 2009; Argunov \& Stepanova, 2011; Argunov et al., 2015).

The aim of the work is to study the geophagia etiology (temporal, seasonal, daily, age and sex) of moose (Alces alces pfizenmayeri Zukowski, 1910) in Central Yakutia.

\section{Methods}

The registration of summer-autumn geophagia of moose with Bushnell and Super Scouter camera-traps was carried out at five natural mineral licks in Central Yakutia, Russia (Fig. 1). During the summer, inspec- tors added rock sodium salt at three salt licks. The camera-traps with the set date and time were fixed on trees at a height of 3-4 m from the ground. The photographing of moving objects was recorded at intervals of 5 seconds. A total of 235 camera-trap-days were spent, breaking down by months as follows: June - 34, July 60, August - 65, September - 60, October - 16. Over this period, they registered 122 single and group visits to the mineral licks. Totally 215 moose visits of the mineral licks were spotted, with the same individuals coming repeatedly. In terms of age and sex, only 31 moose individuals were identified.

The statistical processing of the material was carried out under the standard statistics with the use of the MS Excel.

\section{Results}

As a result of processing the data from the cameras, 122 moose visits $(51.9 \%$ of all camera days) were recorded within 235 camera-trap-days. When counting the camera-trap-days, we assumed only the days with visits; on average $(\mathrm{M} \pm \mathrm{SD}), 3.0 \pm 2.1$ moose visited the salt licks per day, $(\lim =1-8, n=43)$. A total of 31 individuals were recorded at the salt licks during the study 


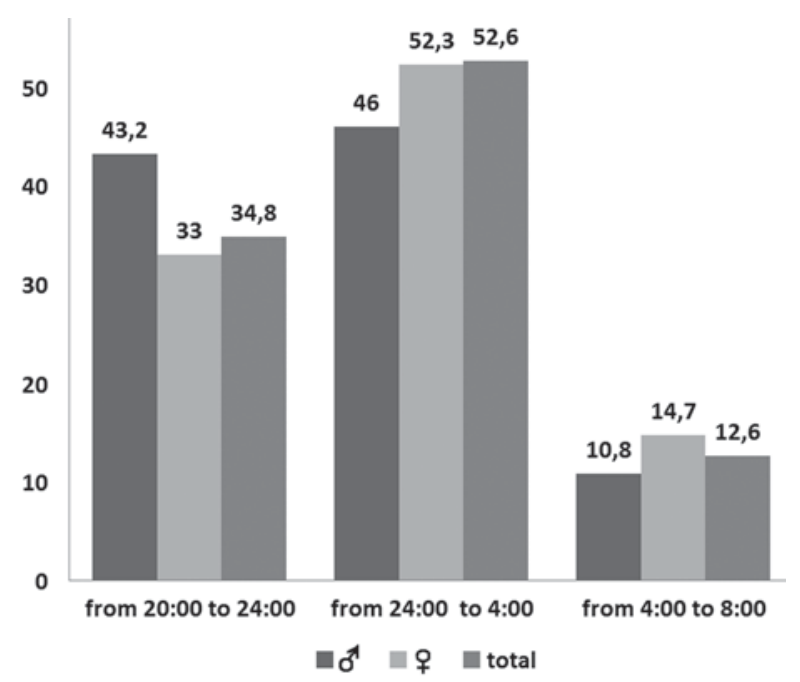

Fig. 3. The temporal distribution of licks attendance by males and females (\%).

period: 10 bulls, 11 cows (including 6 cows with calves) and 10 calves. The maximum number of individuals using lick per day was 7 individuals. There was registered a rare phenomenon in the conditions of Central Yakutia - one cow with 3 calves (Fig. 2).

The duration of lick use by moose was on the average $(\mathrm{M} \pm \mathrm{SD}) 8.7 \pm 7.8 \mathrm{~min}(\mathrm{lim}=1-40 \mathrm{~min}, n=170)$. Other authors also mention the duration of lick use by moose at lim=0-38 min (Ayotte et al., 2008). According to Kaplanov (1948), moose can use lick from 10 to 60 minutes.

The duration of geophagia also differs depending on sex. It was found that cows $(\mathrm{M} \pm \mathrm{SD}=9.2 \pm 7.7 \mathrm{~min}$, $\lim =1-36 \mathrm{~min}, n=90)$ used lick $13.1 \%$ longer than bulls $(\mathrm{M} \pm \mathrm{SD}=8.0 \pm 7.8, \mathrm{lim}=1-40 \mathrm{~min}, n=80)$. The same phenomenon was noted by Rea et al. (2013).

In addition, the difference in staying of animals at the mineral licks is noted depending on the time of day. To determine the daily attendance of the salt licks, we divided the day into two equal parts: from 8:00 to 20:00 and from 20:00 to 8:00. Almost all the time of lick use by the animals fell for the period from 20:00 to 8:00 $94.4 \%$. Next, we divided the period from 20:00 to 8:00 into three parts: the sunset - from 20:00 to midnight; the darkest time of the day - from midnight to 4:00; and the dawn - from 4:00 to 8:00. It should be noted that contrasted with other regions and countries where similar studies have been conducted, the light day in summer (especially in June) in the area of research is stretched and reaches up to 20 hours. In June, the sun sets at about 22:00, the dawn takes place at about 3:00.

According to Kaplanov (1948), moose begin to appear at a salt lick one hour before the sunset and stay there all night and the morning till 8:00-10:00. According to Canadian and American scientists (Fraser et al., 1980; Tankersley \& Gasaway, 1983; Couturier \& Barrette, 1988), moose usually visit mineral licks between the sunset and dawn.

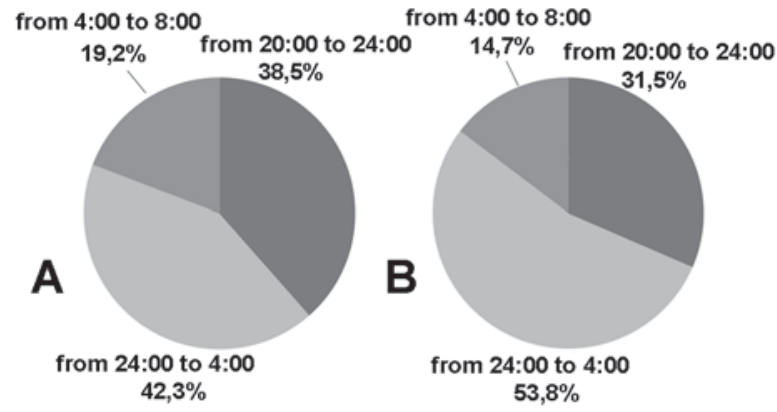

Fig. 4. The temporal distribution of attendance licks females without calves (A, $n=63$ ) and females with calves (B, $n=26$ ) $(\%)$.

Figure 3 shows a sex difference in the daily activity of lick use. Bulls mostly came to the mineral licks from 20.00 to 4.00 , and rarely visited the licks at dawn. Cows were more cautious than bulls, and they visited the mineral licks mostly in the darkest hours of the day, from midnight to 4:00. They were also reluctant to use lick in the morning. Figure 4 shows that there was no significant difference in visiting the mineral licks by the time of day in cows without calves and cows with calves.

The frequency of visits to the mineral licks depending on the nutrition and physiological state of an animal during a certain month. The monthly attendance of the salt licks was as follows: June - 43.3\% (34 cameratrap-days), July - 49.2\% (60 camera-trap-days), August - 5.8\% (65 camera-trap-days), September $1.7 \%$ (60 camera-trap-days), October - 0\% (16 camera-trap-days) (Fig. 5). In Canada and the USA frequent visits to mineral licks were registered in late spring and early summer, i.e. in May and June (Fraser \& Hristienko, 1981; Tankersley \& Gasaway, 1983; Couturier \& Barrette, 1988; Filus, 2002; Rea et al., 2013). Our unpublished data from southern Yakutia provides evidence that animals come to mineral licks less frequently in May than that in June and July. This may be due to the relatively later spring onset and the

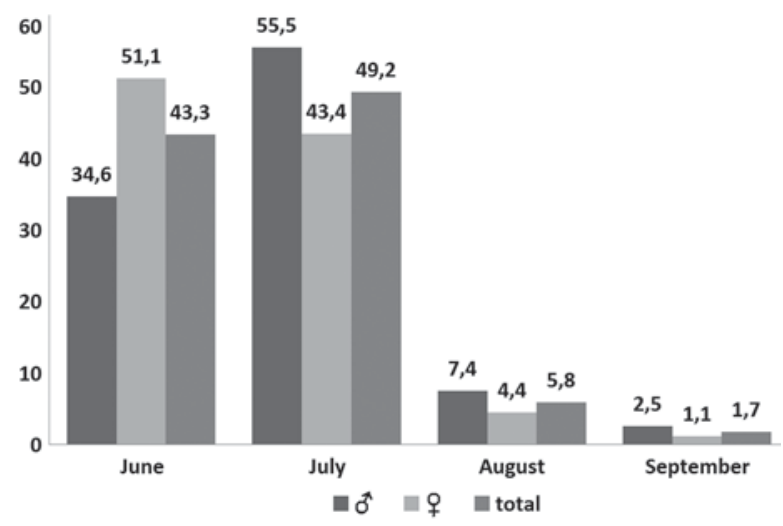

Fig. 5. Monthly attendance of salt licks by males and females $(n=171)(\%)$. 

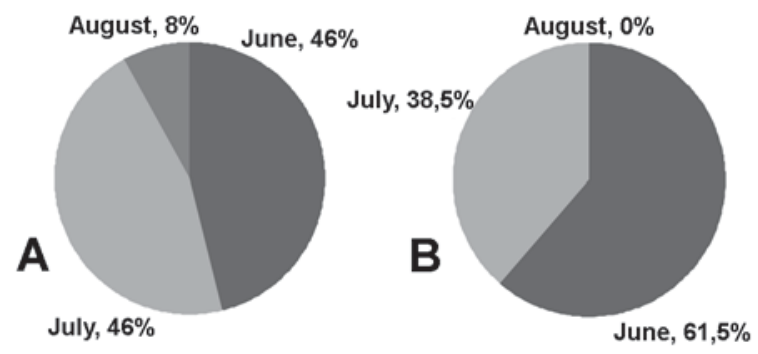

Fig. 6. Monthly attendance of salt licks by females without calves (A, n=63) and females with calves (B, $n=26)(\%)$.

late vegetation of plants in Yakutia than in North America, and subsequently, the later transition from coarse fodder to succulent one.

The sex distribution of lick use by months is slightly different. The lick used by cows in June is $16.5 \%$ higher than in bulls, which is due to calving and lactation of cows. In July, on the contrary, bulls visited the mineral licks $12.1 \%$ more than cows, which is associated with ossification of antlers this month. Tankersley \& Gasaway (1983) note that lick use by cows begins earlier than that by bulls. In August and September, bulls were registered on the mineral licks twice as often as females, which may be explained by the preparation of males for the upcoming rut, fattening up and long migration passages.

Figure 6 demonstrates that females with calves, whose lactation just begins in June, visited the mineral licks in June more than cows without calves, who came to the mineral licks evenly within the two months. The organism needs $40 \%$ more sodium during the early stage of lactation in ungulates (Staaland et al., 1980).

Over the entire period of the research, we have not registered great difference in the frequency of lick use in bulls and cows. The sex ratio of using the salt mineral licks was as follows: bulls - 47.6\% $(n=10)$, cows $52.4 \%(n=11)$.

Out of 122 visits by females, cows with calves visited 24 times, which makes $19.7 \%$. The calves made $32.2 \%(n=10)$ in the population structure. Half of the registered cows had calves $(54.5 \%, n=6)$. Half of the cows with claves had only one calf $(50.0 \%$ of the cows with calves, $n=3$ ).

\section{Conclusion}

The research results in the following conclusions:

1) The duration of geophagia of moose takes from 1 to 40 minutes. Cows use licks $13.1 \%$ longer than bulls.

2) Moose come to the mineral licks mainly during the dark hours from 20.00 to 8.00. Cows are more cautious than bulls, and they are usually observed at the mineral licks after the midnight.

3) In our case, the percentage of attendance was high in June-July, though in June the number of cameratraps-days halved compared with the following months. This fact is explained by the greatest requirement of wild ungulates in mineral nutrition during the growth of antlers and during lactation for cows. In the following months (August-September), the geophagia of moose fell sharply and it dropped to zero in October.

4) In June, cows visit the salt licks more frequently than bulls, which are caused by calving and lactation of the cows. In July, on the contrary, bulls prevail, which is associated with the ossification of antlers this month. In August and September, males are registered on the mineral licks twice as often as cows, which may be explained by the preparation of males for the upcoming rut, fattening up and long migration passages.

5) Cows with calves, whose lactation just starts in June, visit the mineral licks more in June than cows without calves, which come to the mineral licks evenly within the two months.

6) The sex ratio in the population is $1: 1$, with the calves making $32.2 \%$ in the population structure.

ACKNOWLEDGMENTS. The research is supported by grant No. 12-04-98513 from the Russian Foundation for Basic Research.

\section{References}

Argunov A.V. \& Stepanova V.V. 2011. [The structure of the diet of the Siberian roe deer in Yakutia] // Ekologiya. No.2. P.144-147 [in Russian, with English summary].

Argunov A.V., Krivoschapkin A.A. \& Boeskorov G.G. 2015. [Roe deer of Central Yakutia]. Novosibirsk: Izdatel'stvo SO RAN. 123 p. [In Russian]

Ayotte J.B., Parker K.L. \& Gillingham M.P. 2008. Use of natural licks by four species of ungulates in Northern British Columbia // Journal of Mammalogy. Vol.89. No.4. P.1041-1050.

Ayotte J.B., Parker K.L., Arocena J.M. \& Gillingham M.P. 2006. Chemical composition of lick soils: functions of soil ingestion by four ungulate species // Journal of Mammalogy. Vol.87. No.5. P.878-888.

Bgatov V.I. 1993a. [Approaches to ecology]. Novosibirsk: Izdatel'stvo Novosibirskogo Gosudarstvennogo Universiteta. 221 p. [In Russian]

Bgatov V.I. 1993b. [Approaches to ecogeology. Life and geological environment]. Novosibirsk: Izdatel'stvo Novosibirskogo Gosudarstvennogo Universiteta. 22 p. [In Russian]

Bgatov V.I. 1997. [Approaches to the study of geophagia] // Prirodnye mineraly na sluzhbe cheloveka. Cbornik tezisov mezhdunarodnoy nauchno-prakticheskoy konferentsii. Novosibirsk. P.2-10 [in Russian].

Bgatov V.I. 2000. [Area of mineral nutrition of biota - one of the main objects of study of environmental geology] // Ekologicheskaya geologia i ratsional'noe prirodopolzovanie. Materialy mezhvedomstvennoy konferentsii. SanktPeterburg. P.15-16 [in Russian].

Carbyn L.N. 1975. Factors influencing activity patterns of ungulates at mineral licks // Canadian Journal of Zoology. Vol.53. P.378-384.

Couturier S. \& Barrette C. 1988. [The behavior of moose at natural mineral springs in Quebec] // Canadian Journal of Zoology. Vol.66. P.522-528. 
Dravert P.L. 1922. [On geophagia] // Sibirskaya Priroda. No.1. P.3-6 [in Russian].

Filus I.A. 2002. Moose behavior at salt licks // Alces. Suppl.2. P.49-51.

Fraser D. \& Hristienko H. 1981. Activity of moose and white-tailed deer at mineral springs // Canadian Journal of Zoology. Vol.59. P.1991-2000.

Fraser D.E., Reardon F.D. \& Loescher B. 1980. Sampling problems and interpretation of chemical analysis of mineral springs used by wildlife // Journal of Wildlife Management. No.44. P.623-631.

Hebert D. \& Cowan I.M. 1971. Natural salt licks as part of the ecology of the mountain goat // Canadian Journal of Zoology. Vol.49. P.605-610.

Heikillä R. \& Härkönen S. 1998. The effects of salt stones on moose browsing in managed forests in Finland // Alces. No.34. P.435-444.

Kaplanov L.G. 1948. [Tiger. Wapiti. Moose] // Materialy k poznanyu fauny i flory SSSR, izdavaemye MOIP. Novaya Seria. Otdel Zool. No.14. Moscow: Izdatel'stvo MOIP. 128 p. [In Russian]

Lavelle M.J., Phillips G.E., Fischer J.W., Burke P.W., Seward N.W., Stahl R.S., Nichols T.A., Wunder B.A. \& VerCauteren K.C. 2014. Mineral licks: motivational factors for visitation and accompanying disease risk at communal use sites of elk and deer // Environmental Geochemistry and Health. Vol.36. No.6. P.1049-1061.

Murie A. 1934. The moose of Isle Royale // Michigan: University of Michigan Press; Museum of Zoology. Miscellaneous Publications. No.25. P.1-66.

Nasimovich A.A. 1938. [To the knowledge of the mineral nutrition of wild animals of the Caucasus Nature Reserve] // Trudy Kavkazskogo Zapovednika. No.1. P.4954 [in Russian].

Panichev A.M. 1987a. [Mineral licks] // Okhota i Okhotniche Khozaystvo. No.6. P.14 [in Russian].

Panichev A.M. 1987b. [Mineral licks of the Sikhote-Alin] Vladivostok: Izdatel'stvo DVNZ AN SSSR. 206 p. [In Russian]
Panichev A.M. 1990. [Geophagia in the world of animals and humans]. Moscow: Nauka. 224 p. [In Russian]

Panichev A.M. 1998. [Geophagia in animals and humans]. Avtoreferat diss. ... doct. biol. nauk. Vladivostok. 59 p. [In Russian]

Panichev A.M. 2017. [Mineral licks as a phenomenon and an indicator of adaptation of animals to the conditions of the mountain taiga of the Sikhote-Alin]. Downloaded 20.02.2017 from http://www.fegi.ru/primorye/animals/ panich1.htm [in Russian]

Panichev A.M. \& Golokhvast K.S. 2009. [On causes and effects of geophagial instinct] // Uspekhi Nauk o Zhizni. No.1. P.70-81 [in Russian].

Panichev A.M. \& Gulkov A.N. 2001. [Natural minerals and cause medicine of the future]. Vladivostok: Izdatel'stvo DVGTU. 210 p. [in Russian]

Rea R.V., Hodder D.P. \& Child K.N. 2013. Year-round activity patterns of moose (Alces alces) at a natural mineral lick in North Central British Columbia, Canada // Canadian Wildlife Biology and Management. Vol.2. No.1. P.36-41.

Shaposhnikov F.D. 1953. [About licking mineral licks of wild ungulates in the mountain taiga of the Altai] // Byulleten' Moskovskogo Obshchestva Ispytatelei Prirody. Vol.58. No.1. P.3-10 [in Russian].

Staaland H., White R.G., Luick L.J. \& Holleman D.F. 1980. Dietary influences on sodium and potassium metabolism of reindeer // Canadian Journal of Zoology. No.58. P.1728-1734.

Stepanova V.V. 2003. [Daily activity and nutrition Cervus elaphus (Artiodactyla, Cervidae) in Yakutia] // Zoologicheskii Zhurnal. Vol.82. No.6. P.724-730 [in Russian, with English summary].

Stepanova V.V. \& Okhlopkov I.M. 2009. [Ecology of red deer of Yakutia]. Novosibirsk: Nauka. 135 p. [In Russian]

Tankersley N.G. \& Gasaway W.S. 1983. [Mineral lick use by moose in Alaska] // Canadian Journal of Zoology. Vol.61. P.2242-2249. 